University of Chicago Law School

Chicago Unbound

Journal Articles

Faculty Scholarship

1997

\title{
The Implementation of Constitutional Rights: Insights from Law and Economics
}

Gerald Rosenberg

Follow this and additional works at: https://chicagounbound.uchicago.edu/journal_articles

Part of the Law Commons

\section{Recommended Citation}

Gerald Rosenberg, "The Implementation of Constitutional Rights: Insights from Law and Economics," 64 University of Chicago Law Review 1215 (1997).

This Article is brought to you for free and open access by the Faculty Scholarship at Chicago Unbound. It has been accepted for inclusion in Journal Articles by an authorized administrator of Chicago Unbound. For more information, please contact unbound@law.uchicago.edu. 


\title{
The Implementation of Constitutional Rights: Insights from Law and Economics
}

\author{
Gerald N. Rosenberg $\dagger$
}

The study of Law and Economics focuses most often on issues of efficiency and growth. The economic approach has made major contributions, for example, in the areas of regulation, liability, and contract. But an economic approach to the study of courts and law can also shed light on an area that is seldom investigated by traditional legal scholars: the implementation of judicial decisions.

In this essay I demonstrate the relevance of the economic approach to the implementation of constitutional rights. In particular, I show that the economic analysis of law is central to understanding the efficacy of judicial decisions supportive of the interests of relatively powerless groups within society. ${ }^{2}$

Supreme Court decisions are not self-implementing. As Alexander Hamilton pointed out long ago in The Federalist Papers, courts are particularly dependent on the actions of others. Hamilton argued in Federalist 78 that the judiciary "has no influence over either the sword or the purse . . . and must ultimately depend upon the aid of the executive arm even for the efficacy of its judgments." ${ }^{2}$ Without external support-from the other branches of government or directly from the citizenry-Court decisions announcing constitutional rights are unlikely to affect or change people's lives in important ways.

In contrast to traditional legal analysis, the tools of economic analysis can help explain how Court-mandated constitutional rights of relatively powerless groups are actually implemented. In particular, economic analysis suggests that implementation is more likely to occur if at least one of three conditions is present:

$\dagger$ Associate Professor, Department of Political Science and the College and Lecturer in Law, The University of Chicago.

2 Relatively powerless groups are those groups which, due to both past and present discrimination, have limited access to basic goods in American society defined to include "rights and liberties, powers and opportunities, income and wealth" and "self-respect." John Rawls, $A$ Theory of Justice 42, 440 (Harvard 1971). In mid- and late-twentieth century America, such groups include, at the very least, ethnic and racial minorities, and women.

2 Federalist 78 (Hamilton) in Clinton Rossiter, ed, The Federalist Papers 464, 465 (Mentor 1961). 
(1) non-court actors offer incentives for compliance; (2) non-court actors impose costs for non-compliance; (3) court decisions allow for market implementation. ${ }^{3}$ The explanatory power of this economic analysis can be illustrated by examining two famous $\mathrm{Su}-$ preme Court decisions finding constitutional rights that favor the claims of relatively powerless groups within society, Brown $v$ Board of Education ${ }^{4}$ and Roe $v$ Wade. ${ }^{5}$

\section{CIVLL RIGHTS ${ }^{6}$}

In 1954, the Supreme Court in Brown found that state laws requiring race-based segregation in public elementary and secondary schools violated the Equal Protection Clause of the Fourteenth Amendment. Overturning nearly sixty years of Courtsanctioned racial segregation, Brown is heralded as one of the Court's greatest decisions. In particular, Brown is the paradigm of the Court's ability to protect rights and bring justice to minorities. $^{7}$

But a decade after Brown, little had changed for most African-American students living in the eleven states of the former Confederacy that required race-based school segregation by law. For example, in the 1963-64 school year, barely one in one hundred (1.2 percent) of these African-American children was in a nonsegregated school. ${ }^{8}$ For nearly ninety-nine of every one hundred African-American children in the South a decade after Brown, the finding of a constitutional right had changed nothing. However, by the 1972-73 school year, over 91 percent of these African-American children were in nonsegregated schools. ${ }^{9}$

The traditional legal explanation for the lack of desegregation in the first decade after Brown, and the dramatic change in the second decade after Brown, is that the Court's initial stan-

$s$ These points are developed in Gerald N. Rosenberg, The Hollow Hope: Can Courts Bring About Social Change? ch 1 (Chicago 1991).

347 US 483 (1954).

5410 US 113 (1973).

- For further development of the argument in this section, see Rosenberg, Hollow Hope at ch 2-3 (cited in note 3 ).

7 To the human rights activist Aryeh Neier, Brown is the great "symbol" of courts' ability to protect rights and produce significant social reform. Aryeh Neier, Only Judgment: The Limits of Litigation in Social Change 57 (Wesleyan 1982). For Jack Greenberg, long-time civil rights litigator, Brown is the "principal inspiration to others" who seek change and the protection of rights through litigation. Jack Greenberg, Litigation for Social Change: Methods, Limits and Role in Democracy, 29 Record of the Assn of the Bar of the City of New York 320, 331 (1974).

see Table 1.

$s$ See id. 
dard of "all deliberate speed"10 was too loose, allowing school districts to procrastinate. ${ }^{11}$ This changed, it is argued, as the Court came to require more of school districts in cases like Cooper $v$ Aaron, ${ }^{12}$ Goss $v$ Board of Education of Knoxville, ${ }^{13}$ Griffin $v$ Prince Edward County, ${ }^{14}$ Green $v$ County School Board of New Kent County, Va. ${ }^{15}$ Alexander v Holmes County, ${ }^{16}$ and Swann v Charlotte-Mecklenburg Board of Education. ${ }^{17}$

By itself, this legal explanation fails to persuade because it neglects fundamental changes in political, social, and economic contexts. ${ }^{18}$ In particular, it overlooks a set of economic incentives and costs created by Congress and applied with the cooperation of the Departments of Health, Education, and Welfare ("HEW") and Justice. Change came to Southern school systems in the wake of congressional and executive branch action. Title VI of the 1964 Civil Rights Act permitted HEW to cut off federal funds to programs in which racial discrimination was practiced, and the 1965 Elementary \& Secondary Education Act ${ }^{19}$ provided a great deal of federal money to generally poor Southern school districts. As Table 1 shows, by the 1971-72 school year, federal funds constituted between 12 and 27.8 percent of Southern state school budgets, up

10 Brown v Board of Education, 349 US 294, 301 (1955) (“Brown II").

"For example, as late as 1963, Briggs v Elliott, 103 F Supp 920 (E D SC 1952), and Davis v Prince Edward County, 103 F Supp 337 (E D Va 1952), two of the original school desegregation cases, commenced in 1951 and 1952 respectively, were still being litigated. Other school desegregation cases noteworthy for seemingly interminable litigation include Singleton $v$ Jackson Municipal Separate School District, 348 F2d 729 (5th Cir 1965), in which approximately thirty opinions and orders were issued over a seven-year period, and United States $v$ Montgomery County Board of Education, 395 US 225 (1969), in which there were 77 docket entries between 1964 and 1969.

${ }^{12} 358$ US 1, 16 (1958) (holding that suspension of desegregation not justified by violence, or threat of violence, in response to desegregation and resulting turmoil that disrupts the educational process).

${ }^{13} 373$ US 683, 688 (1963) (invalidating one-way student transfers from schools where transferee's race is a minority to one where it predominates).

14 375 US 391 (1964) (invalidating the closing of Prince Edward County public schools to avoid desegregation and the use of state tuition grants and tax credits to support private segregated education for white children).

${ }^{25} 391$ US 430, 439 (1968) ("The burden on a school board today is to come forward with a plan that promises realistically to work, and promises realistically to work now.").

${ }^{16} 396$ US 19, 20 (1969) (holding that "continued operation of segregated schools under a standard of allowing 'all deliberate speed' for desegregation is no longer constitutionally permissible").

${ }^{17} 402$ US 1, 30 (1971) (upholding the power of district judges to include busing as part of a remedial decree).

${ }^{18}$ For example, by 1963, nine years after Brown and five years after the confrontation at Central High School in Little Rock, Arkansas that resulted in the Supreme Court ordering immediate desegregation in Cooper, only 69 of 7,700 students ( 1 percent) at Little Rock's formerly all-white junior and senior high schools were African-American. Rosenberg, Hollow Hope at 84 (cited in note 3).

${ }_{19} 20$ USC $\S \S 2701$ et seq (1994). 
from between 4.6 and 11.1 percent in the 1963-64 school year. This combination of federal funding and Title VI gave the executive branch a tool to induce desegregation when it chose to do so. When HEW began threatening to cut off funds to school districts that refused to desegregate, dramatic change occurred. By the 1972-73 school year, over 91 percent of African-American school children in the eleven Southern states were in integrated schools, up from 1.2 percent in the 1963-64 school year. With only the constitutional right in force in the 1963-64 school year, no more than 5.5 percent of African-American children in any Southern state were in school with whites. By the 1972-73 school year, when economic incentives were offered for desegregation, and costs imposed for failure to desegregate, in no Southern state were fewer than 80 percent of African-American children in integrated schools.

Federal funding was not the only economic inducement for desegregation in the late 1960s and early 1970s. Another powerful factor at work was the desire of many Southern communities to attract industry, and a peaceful, desegregated school system was seen as an important inducement. ${ }^{20}$ Hungry for new industry, the less industrialized South had a strong economic incentive to desegregate.

The courts, therefore, had extra-judicial tools that increased the power of their decisions. School districts that violated court orders risked not only the loss of federal funds but also an important competitive advantage in attracting new industries to their communities. On the other hand, school districts that did desegregate maintained eligibility for federal funds and their communities could make a stronger pitch for new industry. School desegregation occurred in the years 1968-72 because a set of conditions provided incentives to desegregate and imposed costs for failing to do so. When those conditions were lacking, as in the first decade after Brown, constitutional rights were flouted. Thus, an economic analysis sheds considerable light on the implementation of the constitutional right announced in Brown.

\section{ABORTION}

An analysis of the Supreme Court's 1973 landmark abortion decisions, Roe $v$ Wade ${ }^{21}$ and Doe $v$ Bolton, ${ }^{22}$ provides an illumi-

${ }^{20}$ Rosenberg, Hollow Hope at 101-02 (cited in note 3).

${ }^{21} 410$ US 113 (1973).

22410 US 179 (1973). 
nating comparison. ${ }^{23}$ In Roe, the Court held that a pregnant woman, in consultation with a doctor, had a broad constitutional right to terminate a pregnancy without state interference during the first two trimesters of pregnancy. ${ }^{24}$ In Doe, the Court rejected a Georgia law mandating that abortions be performed in accredited hospitals. ${ }^{25}$

Roe, like Brown, is seen as a symbol of the ability of courts to provide constitutionally guaranteed rights that further the interests of relatively powerless groups within society. As one newspaper editorial put it, "No victory for women's rights since enactment of the 19th Amendment [giving women the right to vote] has been greater ... . ${ }^{26}$ Did Roe make abortion accessible? If so, why?

Traditional legal analysis provides little insight into the implementation of Roe. Under such an analysis, if women have a constitutional right to obtain a legal abortion, then women should be able to exercise that right. Thus, one might expect a steady increase in the number of legal abortions performed after the decision, ${ }^{27}$ with abortion available throughout the country. An economic analysis, however, would be less sanguine, suggesting large variation in the accessibility of abortion services, depending on the presence of incentives, costs, and market forces.

Data on the number of legal abortions performed over time illustrate this point. They show a slow but steady rise in the number of legal abortions performed in 1973 and the years following. There was no large jump in the number of legal abortions performed, measured either numerically or percentage-wise, in 1973 or in any of the years following. Indeed the largest increases in the number of legal abortions occurred in the years prior to Roe and Doe. Further, the abortion rate (a standardized measure of the number of abortions per one thousand women of childbearing age in the population) varies enormously across states and over time. Even proximate and adjacent states have very different rates (Delaware three times West Virginia, Rhode Island twice Maine, New York twice Pennsylvania, Alabama twice Mississippi, Nevada twice New Mexico and four times Idaho and Utah,

${ }^{23}$ For further development of this argument, see Rosenberg, Hollow Hope at ch 6 (cited in note 3). See also Gerald N. Rosenberg, The Real World of Constitutional Rights: The Supreme Court and the Implementation of the Abortion Decisions, in Lee Epstein, ed, Contemplating Courts 390-419 (CQ 1995).

${ }^{24}$ Roe, 410 US at 164-65.

${ }^{25}$ Doe, 410 US at $193-95$.

26 Editorial, A Woman's Right, Evening Star A4 (Jan 27, 1973).

${ }^{27}$ Assuming, of course, constant and unmet demand. 
California twice Oregon, etc.). ${ }^{28}$ Such a finding is hard to explain if constitutional rights are equally available across the nation. ${ }^{29}$

These data suggest some, but uneven, implementation. How is it, one might wonder, that there was essentially no desegregation in the wake of Brown but an increase in the number of legal abortions after Roe? The puzzle becomes more complex when one examines how hospitals responded to the Court's finding of a constitutional right to abortion. In general, in the wake of Roe, hospitals, the existing institutions that provided medical care and childbirth services, refused to implement the decision. Indeed, fewer than one-third of private, short-term, non-Catholic hospitals, and no more than one-fifth of public hospitals, have ever performed an abortion..$^{30}$ Like public schools and desegregation, the existing institutions ignored the law. Constitutional rights were protected under law, and constitutional rights were unavailable in practice.

The solution to the puzzle is that one of the conditions necessary for court efficacy was present with Roe but missing in Brown: market implementation. Unlike desegregation after Brown, there was a market mechanism for overcoming the unwillingness of hospitals to act. In Doe, the Georgia case argued with Roe, the Court invalidated a Georgia law mandating that abortions be performed in accredited hospitals. The decision provided a way around the refusal of existing institutions to perform abortions. ${ }^{31}$ This is important because there was public support for the substance of Roe, access to abortion, and demand for the service. A national abortion repeal movement was flourishing with widespread support among relevant professional elites and rapidly growing public support. By the eve of the Court's decisions eighteen states had reformed their restrictive abortion laws to some degree. Indeed, in 1972, the year before the decisions, there were nearly 600,000 legal abortions. ${ }^{32}$ In contrast, while it is true that Brown did not prohibit individuals from opening integrated private schools in the South, the reality was that no whites would have attended them. With abortion, however, there

\footnotetext{
${ }^{28}$ Stanley K. Henshaw and Ellen Blaine, Abortion Services in the United States: Each State and Metropolitan Area, 1981-1982 (Guttmacher Institute 1985); Stanley K. Henshaw, et al, Abortion Services in the United States, 1984 and 1985, 19 Family Planning Perspectives 63 (1987).

${ }^{29}$ Although it is possible that varying demand for abortion services explains these differences, it seems implausible that demand should vary so enormously between adjacent and proximate states.

${ }^{30}$ Rosenberg, Hollow Hope at 190 (cited in note 3).

31 Id at 188.

32 Id at ch 6 .
} 
was a demand for the services. Pro-choice activists, feminists, doctors who wanted to expand their practices, and other market actors, were relatively free to respond to the demand. Clinics could and did open to implement the decision. To put the point in straight economic terms, after Brown there was both a supply and a demand problem, while after Roe and Doe, there was no demand problem, and market forces overcame the supply problem.

In the wake of the Court's decisions there was a sharp increase in the number of abortion clinics. ${ }^{33}$ A 1977 report found that clinics opened in large numbers "to fill the need" that hospitals refused to meet. ${ }^{34}$ Between 1973 and 1974, for example, the number of non-hospital abortion providers grew 61 percent. Overall, between 1973 and 1976 the number of non-hospital providers grew 152 percent, nearly five times the rate of growth of hospital providers. In metropolitan areas, the growth rate was 140 percent between 1973 and 1976, five times the rate for hospital providers, while in non-metropolitan areas it was a staggering 304 percent, also about five times the growth rate for nonmetropolitan hospitals. ${ }^{35}$ And, the growth in the number of abortion clinics was matched by the increase in the percentage of abortions performed by them, with 93 percent of all abortions performed in non-hospital settings by 1992. Clinics met the need that hospitals, despite the Court's actions, refused to meet.

In effectively allowing abortions to be performed in clinics as well as hospitals, the Court's decisions allowed a way around the intransigence of hospitals. The decisions allowed individuals committed to safe and legal abortion to make use of the market and create their own mechanisms to meet the demand. They also provided a financial incentive for services to be provided. At least some clinics were formed solely as money-making ventures. Even the glacial growth of hospital abortion providers in the early and mid-1970s may be due, in part, to financial considerations. For example, in a study of thirty-six general hospitals in Harris County (Houston), Texas, the need for increased income was found to be an important determinant of whether hospitals performed abortions. Hospitals with low occupancy rates, and therefore low income, the study reported, "saw changing abortion policy as a way to fill beds and raise income." ${ }^{36}$

${ }^{23}$ See Table 2.

34 Terri Schultz, Though Legal, Abortions Are Not Always Available, NY Times D8 (Jan 2, 1977).

${ }^{35}$ Rosenberg, Hollow Hope at 196 (cited in note 3).

${ }^{36}$ Kathleen A. Kemp, et al, The Supreme Court and Social Change: The Case of Abor- 
While the availability of a market mechanism for implementation led to an increase in the number of legal abortions, it did not do so evenly. The difficulty with market mechanisms is that they are dependent on local beliefs and culture. In places where political leaders or large segments of the population oppose abortion, it is less likely that clinics will open. Thus, the supply of abortion services varies widely across the country. ${ }^{37}$ Each year, hundreds of thousands of women must travel considerable distances to obtain abortion services. Considering that the Court has held that women have a fundamental constitutional right to obtain abortions, and that abortion is the most common surgical procedure performed on American women today, ${ }^{38}$ the drawbacks to the market mechanism as a way to implement constitutional rights are important. The availability of a market mechanism can help implement Court decisions, but it cannot guarantee them.

In sum, the finding of a constitutional right to terminate a pregnancy has not guaranteed access to abortion for women. As the executive director of a Missoula, Montana abortion clinic destroyed by arson in 1993 put it, "[i]t does no good to have the [abortion] procedure be legal if women can't get it. ${ }^{39}$ In highlighting the role of market forces, an economic approach, in contrast to a traditional doctrinal one, goes a long way to understanding the uneven availability of the constitutional right to abortion services.

\section{CONCLUSTON}

The aftermath of Brown and Roe shows the strength of an economic analysis in explaining the implementation of Court decisions finding a constitutional right that favors the claims of relatively powerless groups within society. In both cases, traditional legal analysis is of little help. Through the lens of economic analysis, one is reminded that courts and constitutional rights do not exist in a vacuum, that judicial decisions must be implemented in a world of competing interests. The insights offered by an economic approach, in contrast to a traditional legal one, remind us that the finding of a constitutional right in and of itself says very little about changes in behavior. If constitutional rights

\footnotetext{
tion, 31 W Pol Q 19, 27 (1978).

${ }_{37}$ Because pregnant women seeking abortion services are everywhere a small percentage of the population, local beliefs and culture play an important role in determining the supply of abortion services.

${ }^{33}$ Philip D. Darney, et al, Abortion Training in U.S. Obstetrics and Gynecology Residency Programs, 19 Family Planning Perspectives 158, 161 (1987).

39 Rosenberg, Real World at 417 (cited in note 23) (emphasis omitted).
} 
are to matter, both normatively and empirically, then surely this is an important reminder.

Table $1^{40}$

Percentage of Public Elementary and Secondary School Budgets Received from Federal Funds in Southern States, 1963-72, Selected Years and Percent of African-Americans in School with Whites, 1963-64 and 1972-73

Federal Funds as a \% of State School Budgets

$\begin{array}{lccccc}\text { State } & 1963-64 & 1967-68 & 1969-70 & 1970-71 & 1971-72 \\ \text { Alabama } & 7.6 & 20.2 & 18.4 & 22.5 & 21.5 \\ \text { Arkansas } & 11.1 & 20.0 & 18.9 & 19.0 & 21.2 \\ \text { Florida } & 7.0 & 12.8 & 10.7 & 11.2 & 12.0 \\ \text { Georgia } & 7.1 & 13.8 & 14.3 & 14.0 & 15.7 \\ \text { Louisiana } & 4.8 & 12.7 & 12.0 & 14.2 & 14.6 \\ \text { Mississippi } & 8.1 & 16.8 & 20.9 & 28.1 & 27.8 \\ \text { N. Carolina } & 6.1 & 18.6 & 16.2 & 15.8 & 18.0 \\ \text { S. Carolina } & 7.5 & 17.5 & 15.2 & 19.8 & 18.7 \\ \text { Tennessee } & 8.0 & 17.8 & 14.6 & 15.6 & 14.7 \\ \text { Texas } & 4.6 & 11.2 & 11.5 & 10.3 & 12.5 \\ \text { Virginia } & 9.5 & 12.8 & 14.1 & 11.3 & 14.0\end{array}$

$\%$ of African-Americans in School with Whites

State

Alabama 1963-64

Arkansas

0.0007

1972-73

Florida

0.32

83.5

Georgia

1.5

98.1

Louisiana

0.05

96.4

Mississippi

0.60

86.8

N. Carolina

0.0

82.9

S. Carolina

0.54

91.5

Tennessee

0.003

99.4

Texas

2.7

93.9

Virginia

5.5

80.0

Total:

1.6

92.8

99.3

1.2

91.3

40 Rosenberg, Hollow Hope at 99, 345-46 (cited in note 3). Note: all figures rounded. 


\section{Table $2^{41}$}

Facilities that Provide Abortions 1973-92, Selected Years

Hospitals

Year Number \% of Abortions

19731,281

$1974 \quad 1,471$

$1975 \quad 1,629$

$1976 \quad 1,695$

$1977 \quad 1,654$

1978

1979

1980

1982

1985

1988

1992
1,626

1,526

1,504

1,405

1,191

1,040

855
52

47

40

35

30

25

23

22

18

13

10

7
Non-Hospitals

Number \% of Abortions

346

557

769

872

1,055

1,127

1,208

1,254

1,503

1,489

1,542

1,525
48

54

60

65

70

75

77

78

83

87

90

93

11 Rosenberg, Real World at 414 (cited in note 23). Note: "Non-Hospitals" includes abortion clinics, clinics that provide services in addition to abortion, and physicians' offices. 